IFN Working Paper No. 706, 2007

Poverty in Rural Cambodia: The Differentiated Impact of Linkages, Inputs and Access to Land

Anders Engvall, Örjan Sjöberg and Fredrik Sjöholm 


\title{
Poverty in rural Cambodia: the differentiated impact of linkages, inputs and access to land
}

\section{ANDERS ENGVALL}

Stockholm School of Economics

ÖRJAN SJÖBERG

Stockholm School of Economics

FREDRIK SJÖHOLM*

The Research Institute of Industrial Economics

\begin{abstract}
Cambodia has been growing rapidly over the past few years but still remains one of the poorest countries in East Asia. In particular, poverty is widespread in rural Cambodia. This paper examines rural poverty in Cambodia with a view to furthering our understanding of the factors that might explain its occurrence and persistence. Setting out from the existing literature, it appears that reduced rural poverty in Cambodia would have to rest on two pillars. Firstly, improvements in agricultural productivity are necessary. Secondly, other income earning opportunities for the rural population have to be established. Using the 2004 Cambodian SocioEconomic Survey, and focusing on the binding constraints to development and poverty alleviation, we add detail to this picture. Our econometric results show that the main causes to poverty differ between landowners and landless and between different regions. Inputs to agriculture are critical to the landowning poor whereas linkages with the rest of the economy, while also essential to landowners, are of vital importance to the landless poor if their lot is to be improved.
\end{abstract}

JEL Codes: JEL codes: O12; O13; O18

Keywords: Asia, Cambodia, Poverty, Rural, Agriculture, Linkages 


\section{INTRODUCTION}

The newly released poverty estimates for Cambodia shows unexpectedly strong progress with a decline in poverty rates from about 47 percent of the population in 1994 and 1997 to about 35 percent in 2004 (World Bank, 2006, p. i). Yet, despite the progress made, ${ }^{1}$ Cambodia remains one of the poorest countries in the region. Moreover, raising incomes and declining poverty rates are unevenly distributed in Cambodia. Whereas urban areas have seen relatively large gains in the standard of living, progress in rural Cambodia is considerably more modest. Hence, Cambodian poverty is today a predominantly rural issue: about 90 percent of the poor are found in rural areas and the urban-rural income gap is increasing. In other words, to understand poverty in Cambodia requires an understanding of rural conditions. Such conditions vary substantially between regions (e.g., Mak 2001, pp. 142-143), which presumably is the reason for the observed variation in rural poverty rates.

This paper examines rural poverty in Cambodia with a view to furthering our understanding of the factors that might explain its occurrence and persistence. A host of features have been suggested as important in explaining poverty in Cambodia, ranging from geographical aspects to poor inputs in agriculture and poorly defined land rights. We approach the issue at hand by a careful analysis of the relative importance of different factors. Based on previous literature, our a priori hypothesis is that reduced rural poverty in Cambodia would have to rest on two pillars. First, improvements in agricultural productivity are necessary. Second, other income earning opportunities for the rural population have to be established. The first request includes factors such as land rights, irrigation, and access to fertilizers and modern seeds. It does also include access to health and education. The second factor is concerned with linkages to a modern sector and with access to markets for agricultural products. We contribute to the literature by examining, in some detail, the effect on poverty from the above mentioned factors. 
Any attempt to seriously reduce poverty needs to be based on a careful analysis of its determinants. For one thing, poverty caused by for instance poor infrastructure or titles to land needs a different plan of action than poverty caused by poor seeds or a lack of irrigation. For another, and as has also been observed more generally (e.g., Rigg, 2006), it is not self-evident that rural implies agriculture, or that agriculture - whether it is a question of 'have' or 'have nots' - is straightforwardly related to poverty. In the Cambodian case, it could also be mentioned that the decline in poverty which has taken place so far to a large extent can be explained as a 'peace effect,' that is by an increase in economic activity that can be expected after the resumption of peace and stability (World Bank, 2006, p. i). Further progress is likely to require more focused policies which is, again, a reason why careful analysis of the determinants of poverty is warranted. Recent studies suggest that countries should focus on removing the main constraints to economic growth (Hausman et al., 2005) or poverty alleviation (Lundström and Ronnås, 2006). However, it is not obvious how one should rank different constraints. This might be one explanation for the very different views among policy makers and multilateral organizations on the main reason for rural poverty now prevalent. By way of an example, in Cambodia the government is pursuing a massive campaign to increase irrigation whereas the World Bank is more sceptical of the economic return to such investments. Neither is it obvious that the same constraints are the most important ones across, for instance, geographical areas or farm size classes.

An econometric approach affords an opportunity to evaluate the importance of different constraints for poverty. Such an approach enables us to disentangle the effect on poverty from different factors. Our analysis is based on rich data from the Cambodian SocioEconomic Survey including 15,000 households in 900 villages. We will also specifically examine determinants to poverty in different regions and for different sub-sets of rural households. To do so requires that we take a look at what both theory and previous empirical results suggest. This is where we now turn. 


\section{RURAL POVERTY ERADICATION: A FRAMEWORK}

Occupying three-fifths of the labor force and contributing one-third of GDP implies that agriculture, and therefore rural areas, will have to be at the heart of any strategy to move Cambodia into the ranks of the more affluent. This is especially so as nine-tenths of the poor reside in rural areas. However, rural residents do not necessarily engage in agriculture for a living. Indeed, an important reason for people being poor appears to be that they are not nearly enough engaged in the activities of the primary sector. Restricted access to land, or no access at all, are often seen as an important contribution to rural poverty (e.g., Sik, 2000; Chan and Acharya, 2002). The ability to produce a marketable surplus and to provide an income beyond mere subsistence is an important contribution to poverty alleviation and, in the aggregate, to the development effort more generally.

This of course is not a novel situation. The history of economic development teaches us that this is a common starting point in countries that have not been able to move out of poverty and, indeed, in those that successfully have done so. The literature of development economics clearly reflects this, but there is precious little agreement on how to improve on this situation in a decisive manner. While many economists today argue that there is nothing, in principle, that sets countries at low levels of development aside from those that have been successful (Krugman, 1995; Lazear, 2000), others point to a number of structural features that are likely to be a direct constraint on the ability to move to higher levels of income (Fine, 2002; Kanbur, 2002).

Early work in this vein includes Lewis (1954) which posited that an nearly unlimited supply of unskilled labor would prevent an economy to get off the ground. No matter the demand from the modern, or urban, sector, the effect on rural areas would be small. This is so as marginal productivity, at zero or close to zero rates, is abysmally small. Underemployment being widespread, agriculture in effect serves as a labor sink or buffer to the economy, the immediate consequence of which would be that further absorption of labor would do little to 
increase output while very substantial shifts of labor out of this sector would be required to increase the productivity of those remaining in agriculture. Demand for labor from the small modern or non-subsistence sector could not possibly help engineer this shift at a large enough scale to make a noticeable impact unless an expansion of the non-agricultural sector was underwritten by substantially increased levels of capital accumulation. Lewis (1954, p. 155) therefore famously suggested that the crux of the matter was to increase the rate of savings from 4 or 5 percent of national income to a level three times as high, something echoed in other work (e.g. Rostow, 1956) that shared many of the assumptions of the classical theory of capital accumulation associated with Harrod (1939) and Domar (1946). To Lewis' credit, he pointed to the lack of a discussion of the process whereby this change in savings behavior might occur.

Much of the subsequent deliberations with respect to Lewis' contribution to the theory of economic development has focused on the existence of an at least initially infinitively elastic supply of labor at the subsistence wage (for a review, see Kirkpatrick and Barrientos, 2004). Many observers, who are perhaps less sanguine about the positive effects of savings than was Lewis, have been less pessimistic as far as the ability of agriculture to move up the productivity ladder. It is beyond the scope of this discussion to rehearse the arguments and empirical findings wielded to sustain the various positions taken. Rather we would like to point out that this and other early models of economic development typically assumed a closed economy. Domestic saving would therefore be very important, as capital accumulation in the modern sector would be the sole driver of economic growth. Without it, the economy could not be expected to move anywhere near the point where the productivity of agricultural labor would begin to rise as a consequence of an ever larger outflow of labor to the non-agricultural activities. However, it also points to the importance of a marketable surplus and suggests that technical change must take place so as to allow such a surplus under conditions where the population continues to expand at high rates. 
The marketable surplus is of little use unless demand from the non-agricultural sector for food and other agricultural products keep up. Such demand acts as a constraint on the agricultural sectors' ability to move beyond the subsistence level and to reach the commercialization point where productivity of labor in agriculture starts to increase at a rate allowing for improvements in real incomes of those engaged in agricultural production. In an open economy setting, demand needs of course not be domestic but could issue form foreign markets; on the other hand, domestic agriculture might find itself competing with imports to such an extent that national markets are blocked for domestic producers.

The approach taken here is a modified Lewisian one. It is modified in that we move away from the assumption of a closed economy. Furthermore, we do no necessarily accept a spatially undifferentiated, unlimited supply of labor and the rather bleak prospects for productivity growth that Lewis' original ideas imply. Marginal productivity may well be zero, or close to zero, across much of the agricultural sector, but because demand for labor and land is spatially uneven (e.g., Acharya et al., 2003), this need not be universally true. Similarly, given that transport costs - and at times the conditions under which fresh produce can be distributed and marketed - vary spatially, prospects for accessing the market with any marketable surplus will be likewise differentiated.

It is equally clear, however, that agricultural incomes cannot be much improved unless labor can also be released into other activities with higher levels of productivity. This is especially so in Cambodia, where the ability of agriculture to absorb still more labor appears to be approaching its limit. If Lundström and Ronnås (2006) are correct in their analysis, this role has already shifted to the informal non-agricultural sector, which is no better at holding up productivity levels, and hence incomes, than is agriculture.

Lewis' contention that savings might do the trick is of little comfort here. This is so as the savings ratio in Cambodia is around 15 percent of GDP (International Monetary Fund, 2006, p. 35). By regional standards this appears to be small and the Cambodian savings rate is 
half or less than that of Malaysia, Thailand or Vietnam. Meanwhile, foreign savings in the form of foreign direct investment have declined over the past half a decade or so, while overseas development assistance can hardly be expected to grow much further in a country which receives about 10 percent of GDP in support from donors (9.8 \% of GDP in 2004; UNDP, 2006, p. 345) and which already is one of the most aid dependent in the region.

To sum up the discussion above, then, rural incomes are dependent on output in production (agriculture) and on linkages with other sectors of the economy. These linkages may take the form of access to markets for agricultural produce or access to other (non-agricultural) streams of income. The simple figure below outlines the main arguments.

-- Figure 1 about here --

Thus, linkages will affect investment in agricultural production both through market for agricultural products and through remittances that are used for investment. ${ }^{2}$ Markets are important since they provide opportunities for a move away from subsistence farming to a more cash-crop oriented one - and such a move, if successful, will generate income. Investment can take the form of irrigation (e.g., water pumps) or other infrastructure, or the use of high yield seeds and fertilizers. Linkages will also have a direct effect on consumption through remittances.

Previous studies offer some support of the importance of linkages in explaining poverty. For instance, the World Bank (2006, p. vi) finds in a comparison of household in all Cambodia (rural and urban) that poor households tend to have relatively less access to allweather roads and markets. Although this is not particularly surprising in view of the fact that there are few poor who reside in urban areas, the chances are that the rural poor are disadvantaged also relative the rural non-poor in this respect. Furthermore, the rural poor tend to have little access to water pumps and irrigation. 
The picture may also have to be looked at in greater detail. As part of the World Bank's Moving Out of Poverty project, the Cambodia Development Resource Institute (CDRI) surveyed poverty in nine villages in 2001 and 2004/05 (with data on some of them going back to 1996). While the country report is not yet available, So and Kem (2005) provide some preliminary findings. Poverty fell in six villages and rose in three. It was found that improved roads and opportunities for wage labor were important factors explaining poverty reduction. The pattern of improvement was such, however, that no straightforward connection between overall performance at the village level and the incidence of poverty could be established. Specifically reporting on two villages of the sample of nine, it was found that the one that saw the greatest progress in the form of agricultural development was also the one where the proportion of rural poor increased the most, in effect displaying an intra-community pattern of increased polarization. The poorer of the two villages, on the other hand, saw improvements despite growing difficulties in agriculture, an increase in the incidence of landlessness and reduced access to common property resources. Here, incomes from non-agricultural jobs - Phnom Penh not being very far away - did provide an alternative that helped sustain several families.

\section{INCOMES AND POVERTY IN CAMBODIA}

Cambodia came out of the extreme turbulence of the 1970 s and 80 s as a very poor country. However, due to lacking institutional capacity, or even control of the whole country by the central government, there was no notion of exactly how severe poverty was. The Cambodian Social Economic Survey of 1994 (CSES, 1994) revealed that roughly 39 percent of the population was below the poverty line. Due to security reasons the survey could only sample part of the country and a considerable portion of the presumably poorer parts of Cambodia had to be left out (Knowles, 2005, p. v), suggesting that the true poverty figure was higher. In 1997, another similar survey was conducted, including more provinces but with the drawback of recording 
consumption in one month only. This survey suggested that the poverty rate had been roughly stable between 1994 and $1997 .^{3}$

One unsuccessful attempt to measure poverty in 1999 was followed by years without any new solid information on how the incidence of poverty was developing. Fragmented evidence from small scale surveys suggested that the situation was one of little progress being made. For instance, UNDP (2005) reported that about one-third of the population lived below the poverty line, only a small decrease from the 39 percent in 1994. Other reports suggested that poverty has increased over the period 1999-2003. For instance, a relatively recent study by the World Bank estimated that about 45.5 percent of the population was considered poor in 2003, up from 41.5 percent in 1999 (EIC, 2004, p. 39). Similarly, IMF (2004d, p. 34) reported an increase in poverty from around 37 percent of the population in 1996 to about 42 percent in 2002.

Therefore it came as something of a positive surprise that the CSES 2004 recorded a substantial drop in the rate of poverty between 1994 and 2004. The poverty headcount rate had declined, it was inferred from the survey, from 39 to 28 percent in the geographically comparable area. All provinces were included in the CSES 2004 but as previously said large areas were left out of the survey in 1994. Using the results for the whole country in 2004 and making backward projections for the whole country in 1994, it was estimated that poverty fell from around 47 percent of the population in 1994 to around 35 percent in 2004. It was also found that poverty varied substantially between urban and rural areas which is seen in Table 1 where figures are only based on those regions that are available in both 1994 and 2004. The sharpest fall in poverty is seen in urban areas in general and in Phnom Penh in particular. In the capital only an estimated five percent of the population was below the poverty line in 2004 as compared to 21 percent in other urban areas and 34 percent in rural areas.

--Table 1 about here-- 
Hence, poverty is predominantly a rural phenomenon and based on the CSES it is estimated that 91 percent of all poor are living in rural areas. As can be gleaned form Table 2, however, poverty differs substantially across regions and provinces.

-- Table 2 about here --

The large variation in rural poverty makes its possible to examine its determinants by relating it to variation in other factors. Using the same cut-off point as does the CSES 2004 to define the poor it appears that poor households are disadvantaged compared to the non-poor in a number of respects (Table 3). As previously noted, a common observation is that poverty is partly explained by a lack of integration with the rest of the economy. Thus, while the share of households receiving remittances do not differ much - and receiving household are in a distinct minority, no matter the socioeconomic status of the recipient - the amount of money received differs quite markedly. Similarly, the poor are disadvantaged with respect to access to markets, at least as gauged in the form of physical distance to the nearest regular market place. In particular the access to markets appears to be consistent with the importance of being able to integrate into the economy. As such it is not only consonant with the importance attached to this factor by the World Bank (2005) and others, but also with our modified Lewesian framework where spatially differentiated conditions are not only an essential feature but indeed a potential sign of change for the better.

-- Table 3 about here --

It should be underlined that with the exception of distance to market and receipt of remittances from abroad, differences between rich and poor households are not very pronounced - and even when they are of some magnitude the pattern across regions is not entirely clear cut. 
On the coast and the plateau foreign remittances, for instance, on average benefit poor recipients more than the non-poor, both in absolute and presumably therefore also in relative terms. The same applies to distance, at least in the coastal zone, where the poor enjoy a shorter distance to the market than do the relatively rich.

Most importantly, however, there is one indicator which would seem, superficially at least, to privilege the poor irrespective of where they live: distance to an all weather road. As assessed at the regional level, this is consistently the case, only the coastal zone being an exception in this regard. While it is also true that in some regions the difference is quite small, the provision of serviceable roads is of no small consequence in a country where accessibility is generally poor and the quality of infrastructure typically leaves much to be desired.

There are a number of possible explanations for the observed deviations from the overall pattern. First of all it should be noted that those regions that deviate from the predominant pattern are those at the extremes: the coast is better off than any other region save the capital while the plateau and mountains are far worse off than the others. This alone may skew patterns. Furthermore, rural households living on the coast may have better access to nonagricultural work, including in cities and abroad. If so, this would show up on a more disaggregated level of analysis: provinces with the same favorable locational characteristics would display patterns similar to those on the coast.

There are, however, a few other potential explanations, at least some of which find support in the existing literature on poverty in Cambodia. One is the access to major urban areas, which may allow for commuting to urban jobs or urban informal sector activities (So and Kem, 2005). Although at times no doubt an attractive proposition, indications are that in many instances it may only be so provided that agriculture is not a viable option. To find out, a more detailed analysis of agricultural households in CSES 2004 would be necessary. Another possible explanation is the pattern under which the opening up of new areas by means of new or improved roads leads on to a transfer of land to the local rich or to outsiders who acquire land 
for development or purely speculative reasons, leaving the previous user or owner without enough land to secure a decent livelihood.

At least in part the key to an answer as to which are the causes of the pattern observed revolves around agricultural production as such. Towards this end Table 4 has been assembled. It then appears that the poor have, on average, more land at their disposal than the non-poor. Although this statistic captures all rural dwellers, and therefore includes both the poor without land and the better-off in rural areas who have left agriculture behind, it points to a potential problem in only associating poverty and vulnerability to the non-availability of land. Regional differences are rather pronounced, however, and it is difficult to draw any firm conclusions on the basis of this particular set of descriptive statistics.

-- Table 4 about here --

More informative, then, are the data on crop diversification, providing a first cut at the extent to which farmers specialize. It may also provide a clue as to the extent farmers are depend on a strategy of self-sufficiency, which normally is taken to imply a high reliance on own rice production. While crop diversification is not very prominent, the difference between poor and non-poor is striking and consistent throughout the regions. One reason for this state of affairs, the two final columns of Table 4 suggest, might be that the non-poor also apply higher levels of fertilizers and have better access to irrigation, suggesting in turn that higher (and more reliable) yields are within range for the non-poor. Again, differences are not dramatic, but they are consistent across the sample captured by the CSES of 2004 and clearly indicate that a lack of inputs (here: fertilizers) could be an important correlate, perhaps also cause, of rural poverty. To find out if it is, and whether physical access might be important to the well-being of rural inhabitants, we now turn to the econometric analysis. 


\section{ECONOMETRIC ESTIMATIONS AND RESULTS}

(a) Data

Our empirical analysis is based on the rich household information from the Cambodian Socio-Economic Survey (CSES) 2004. It is the most ambitious survey ever conducted in Cambodia with a sample of 15,000 households drawn from 900 villages. The data includes detailed information at the individual, household and village level. In addition to household consumption of various goods, it includes a wide range of social indicators, the daily time use of all household members, sources of household income, data on land use and access to social services and infrastructure (Knowles, 2005, p. 2).

(b) Empirical analysis

Our econometric analysis starts out from following expression

$C_{i}=\alpha+\beta_{1} X_{i}+\beta_{2} Y_{i}+\beta_{3} Z_{i}+u$,

where $\mathrm{C}$ is per capita consumption in household i, $X$ is linkages with the rest of the economy, $Y$ is inputs to agriculture, $Z$ is control variables, and $u$ is an error term. We will estimate equation 1 by ordinary least square (OLS) using consumption as dependent variable. An alternative measure used in many studies is a binary variable that measure whether or not a household is below the poverty line. The main advantage with this latter approach is that it is well related to poverty but one serious disadvantage is its sensitivity to the definition of poverty.

Table 5 shows our three different categories of variables. Our dependent variable has been discussed above. Linkages will be captured by remittances, distances to all weather roads and economic (commercial) centers, household businesses, and household members working 
abroad. These variables capture the access to other parts of the economy and well developed linkages are expected to have a positive impact on consumption.

We include a number of inputs to agriculture that are likely to have a positive impact on agricultural output and thereby on consumption: land in general and improved land, land rights, irrigation and fertilizers, livestock, and mechanization. We also include a dummy variable for land conflicts which could have a negative impact on agriculture investments and thereby on consumption.

There are of course many other factors that affect poverty and we try to control for these by including a number of control variables that have been suggested in previous literature. The control variables are both controling for household characteristics and for village characteristics.

-- Table 5 about here --

As previously argued, we believe that linkages with other sectors of the economy can increase incomes both through direct effects on consumption and through a higher investment in agriculture production leading on to higher/more reliable yields and thereby a higher level of consumption. One way to evaluate the relative importance of the direct and indirect effect is to start with estimations where only the linkage variables are included (together with the control variables) and continue with estimations with the additional inclusion of input variables. Finally, determinants to poverty are likely to differ between landowners and landless population. In particular, inputs to agriculture are not relevant in an analysis of the latter group. We will therefore make a distinction between the two groups in our econometric analysis. 
(c) Results

We start in Table 6 to estimate consumption per capita in Cambodian households. The first estimation examines the effect of linkages on consumption. It is seen that domestic remittances has a positive effect on consumption. More surprisingly, households with a family member working abroad have a relatively low level of consumption. However, the coefficient is very small and economically insignificant. Finally, households close to economic centres and households with own business activities are relatively better off.

The estimations continue with inclusion of a number of variables on inputs in agriculture. It is seen that households with improved land and with land titles have a relatively high level of consumption. The same positive effect on consumption is found for households with livestock and, in particular, in households that have access to fertilizers. An unexpected result is the negative effect of land size on consumption. This result is not particularly robust, however, and the inclusion of additional variables - as in estimation three where we combine linkages and input variables - easily changes the outcome. Other changes in estimation three are that vicinity to economic centres turns insignificant and that there is a positive effect on consumption from mechanization of agriculture.

There are, as previously said, a number of additional variables that are likely to affect consumption. We try to control for some of them in the last estimation in Table 6 where we add control variables that aim at capturing characteristics of the household as well as characteristics of the village. The result for household characteristics is broadly in line with what is typically found in similar studies on other countries: large households with high dependency ratios and a female head tend to be relatively poor (e.g., Deaton and Paxson, 1998; Ellis and Bahiigwa, 2003; Woolard and Klasen, 2005). Moreover, education improves household consumption. However, literacy has no significant effect, but it could be that any such effect is captured by the education variable. Access to electricity is the only village characteristic that has a significantly positive effect on consumption. 
-- Table 6 about here --

The effect of inputs in agriculture is only relevant for those rural households that are engaged in agriculture. We therefore divide our sample in households with and without land in Tables 7 and 8 . The results for landowners are rather similar to the previous ones. Not surprisingly, most inputs to agriculture have a positive impact on household consumption and the coefficients are of similar size as the previous ones. Moreover, the control variables again show a negative effect on consumption from household size and high dependence ratio and a positive effect from a male head of the household, high education, and access to electricity. The perhaps most important difference between the estimations on landowners and on the whole sample of households is that there is no positive effect of remittances in the former sample (full model). This is in contrast to the estimations on landless in Table 8, where the effect of remittances is positive and statistically significant. Another important finding is that distance to all weather roads is benefiting the landless but not landowners. Hence, one tentative conclusion is that linkages are of most importance for the landless by offering alternative income earning opportunities and that the effect of linkages in agricultural investments might be relatively minor.

To sum up the results so far, it has been seen that both some linkages and some input variables have a positive effect on household incomes. The results seem to suggest that the latter group of variables is perhaps relatively more important. We previously discussed the possibility that linkages might have a direct as well as an indirect effect on incomes. For this reason, the outcome of the analysis is not unambiguously clear, but there is some room to speculate on the respective effects from the obtained results. In statistical estimations on landowning households, remittances, household business, and distance to all weather markets are the three linkage variables that show some evidence of a positive effect on consumption. If the effect from these factors is primarily indirect, that is, working through increased possibilities and 
incentives to invest in agriculture, we would expect the statistical significance to disappear when we control for inputs in agriculture. This does not happen: the same linkage variables remain statistically significant after controling for inputs. What we do find is that the effect of distance to all weather roads and remittances turns insignificant when we control for household and village characteristics. One possible explanation is that remittances have a positive impact on, for instance, education and thereby on consumption. Moreover, the effect of access to all weather roads might be closely related to access to electricity; both might capture an aspect of integration with the surrounding economy.

As previously discussed, household incomes and poverty differ between provinces. Moreover, conditions for agriculture are also very different between regions. It is therefore likely that determinants to poverty show a similar difference between regions, an issue that we examine in more detail in Table 9. Indeed, the hypothesis appears to be borne out: the determinants to poverty differ substantially between the four regions. Starting with linkages, own business is the only variable that increases incomes in all regions. In Tonle Sap and the Mountain region, this is in fact the only linkage variable that has a statistically significant impact on incomes. Distance to commercial center is negative in the Plains and in the Coastal region as is also the case of distance to all weather roads in the latter region alone.

Continuing with inputs, it is seen that most variables are significant in some or the regions, but none in all of the regions. Large and irrigated land area, livestock, and fertilizers are positive for incomes in the Plains; large land area with land titles and fetilizers in the Coastal area; titled and improved land as well as mechanization and use of fertilizers in the Tonle Sap region; and livestock and improved land in the Mountain region.

The effects of control variables are more similar between the regions and largely in line with previous results. One result that might be worth mentioning is that there is no positive effect of access to electricity in the Mountain region, but instead a positive effect of access to health services. 
-- Table 9 about here --

\section{CONCLUSION}

Cambodia has made substantial progress in its economic development over the past decade or so and poverty has been reduced on a significant scale. However, economic growth has been achieved from a very low level of development and sustained attempts at poverty eradication set out from a situation where an overwhelming share of the population lived under very harsh conditions. As a result, Cambodia remains a poor country. The most important change is that incomes have grown rapidly in urban areas and that poverty, consequently, is today primarily a rural phenomenon. That brings rural poverty to the frontline of economic policy. The issue at stake is how rural poverty should be addressed.

Rural poverty is presumably affected by a host of factors and policy advice typically range from improved irrigation for farmers to better access to health and education. Whereas most suggested policies are likely to have an influence on poverty and poverty alleviation, it is difficult from the ongoing discussion to get a precise understanding on how large the effects are from various policies, indeed what policies might make a difference across various contexts to begin with. This is in our view a serious drawback since it makes it difficult to prioritize between different policies. As a step towards addressing this state of affairs, we contribute to the discussion on poverty in Cambodia by means of a quantitative analysis on the determinants of rural poverty.

Our results show that causes of poverty varies within rural Cambodia. It differs between landowners and landless households, and it varies between households in different regions. The policy implication is as important as it is obvious: any successful poverty reduction program has to start by deciding which group in society that is the main target for the planned intervention. 
More specifically, and as expected, inputs to agriculture have a strong positive effect on rural incomes for landowners. Landowning households with large plots of titled, irrigated and improved land have relative high level of consumption. However, all of the linkages do not have a positive effect on incomes in all of the regions, but all of them have a positive effect in some region.

Linkages with the surrounding economy have less of an effect on consumption among landowners although remittances, own businesses, and distance to all weather roads are found to have a positive effect in some estimations. Moreover, our hypothesis of a positive effect of linkages on agricultural investments, and thereby on landowners' consumption, does not receive much support in our econometric analysis. However, there is some evidence of an effect of linkages on incomes through, for instance, increased schooling and through improved infrastructure.

Instead, the main effect of linkages on incomes is found among the rural landless population. Remittances, own businesses, and access to infrastructure presumably improve the ability of the rural landless to find alternative income earning opportunities and has a clear and positive effect on their consumption. In this context it should be noted that this result most likely captures at least two different types of situations. On the one hand, landless poor in close proximity of resources or employment opportunities benefit through the access to alternative sources of income, as is indeed illustrated by the moving out of poverty study conducted by So and Kem (2005) already referred to. On the other, the landless also includes a group that where never landowners or peasants to start with. Teachers, civil servants, and traders can be expected to be at least somewhat better off than land poor, landless or else resource poor agricultural households.

The specific policy implications of these findings are at least three, while an additional observation with a potential bearing on policy can be made. First, non-agricultural employment or income opportunities are essential to the consumption levels of sizeable 
segments of the rural population, including the landless and/or poor, and should therefore be encouraged. Second, education focusing on basic literacy and numeracy is an essential ingredient to the ability to make use of such income generating opportunities as exist. The provision of this basic service should therefore be encouraged and supported. For now access to and costs of primary education is a concern (Bray and Seng 2005), while over time higher levels of educational attainment should presumably be striven for. Third, to create opportunities, and to reap the benefits of opportunities as may already exist, linkages to the wider economy should be supported.

However, at this point we should also note that our results provide no or few clues as to whether the provision of physical access and transport infrastructure may in fact increase polarization. Previous work (e.g., So and Kem, 2005) suggests that agricultural growth may create increased polarization not merely by inceasing top incomes but also reducing access to land and common pool resources by the poor. Furthermore, anecdotal evidence suggests that improved access increases potential land values, a phenomenon that the rich and well-informed are thought to take advantage of - and then presumably at the expense of poor landowners, that are made to part with their land at low prices (e.g., Guttal 2006). This may well be the case, but no evidence to this effect has been detected in the course of our analysis. On the other hand, nor have we found any solid evidence that can be used to refute this presupposition. 


\section{ENDNOTES}

${ }^{*}$ Corresponding Author. The Research Institute of Industrial Economics, Grevgatan 34, Box 55665 SE-102 15 Stockholm, Sweden. Phone + 46866545 39. Email Fredrik.sjholm@ifn.se

${ }^{1}$ It should be pointed out that the results obtained by the World Bank are not endorsed by all knowledgeable observers (for a brief review, see Sjöberg and Sjöholm, 2006).

${ }^{2}$ In Cambodia, previous findings (e.g., ADB, 2001, pp. 25, 44; Dahlberg, 2005) suggest that remittances are available to relatively few households, sums remitted being small and often used for daily consumption needs rather than investments.

${ }^{3}$ The survey was conducted in a setting of political turmoil, which suggests that households consumed less than normal to build up reserves for an uncertain future. Hence, the true poverty is likely to have declined between 1994 and 1997 (Knowles, 2005). 


\section{REFERENCES}

Acharya, Sarthi, Kim Sedera, Chap Sothirith \& Meach Yady (2003). Off-farm and non-farm employment: A perspective on job creation in Cambodia. CDRI Working Paper 26. Phnom Penh: Cambodia Development Resource Institute.

ADB (2001). Participatory poverty assessment in Cambodia. Manila: Asian Development Bank.

Bray, Mark \& Seng Bunly (2005). Balancing the books: Household financing of basic education in Cambodia. CERC Monograph 4. Hong Kong: Comparative Education Research Centre, University of Hong Kong.

Chan Sophal \& Acharya, Sarthi (2002). Facing the challenge of rural livelihoods: A perspective from nine villages in Cambodia. CDRI Working Paper 25. Phnom Penh: Cambodia Development Resource Institute.

Dahlberg, Elisabet (2005). Insights into migration and spending patterns based on a small-scale study of garment workers in Phnom Penh. EIJS Working Paper, 221. Stockholm: Stockholm School of Economics.

Deaton, Angus \& Paxson, Christina (1998). Economics of scale, household size, and the demand for food. Journal of Political Economy, 106(5), 897-930.

Domar, Evsey D. (1946). Capital expansion, rate of growth, and employment. Econometrica, vol. 14(2), 137-147.

Ellis, Frank \& Bahiigwa, Godfrey (2003). Livelihoods and rural poverty reduction in Uganda. World Development, 31(6), 997-1013.

Fine, Bob (2002). Economics imperialism and the New Development Economics as Kuhnian paradigm shift? World Development, 30(12), 2057-2070. 
Guttal, Shalmali (2006). Land and natural resource alienation in Cambodia. Bangkok: Focus on the Global South. Online resource available from http://ww.landaction.org/spip.ph?article148 [accessed 8 May 2007].

Harrod, R.F. (1939). An essay in dynamic theory. Economic Journal, 49(193), 14-33.

Hausman, Rircardo, Rodrik, Dani \& Velasco, Andres (2005). Growth diagnostics. Unpublished paper. Cambridge, MA: Kennedy School of Government, Harvard University.

IMF (2006). Cambodia: Selected issues and statistical appendix. IMF Country Report 06/265. Washington, DC: International Monetary Fund.

Kanbur, Ravi (2002). Economics, social science and development. World Development, 30(3), 477 486.

Kirkpatrick, Colin \&Barrientos, Armando (2004). The Lewis model after 50 years', The Manchester School, 72(6), 679-690.

Krugman, Paul (1995). Development, Geography, and Economic Theory. Cambridge, MA: MIT Press.

Lazear, Edward (2000). Economic imperialism. Quarterly Journal of Economics, 115(1), 99-146.

Lewis, W. Arthur (1954). Economic development with unlimited supplies of labour. Manchester School of Economic and Social Studies, vol. 22 (2), pp. 139-191.

Lundström, Susanna \& Ronnås, Per (2006). Employment and growth in Cambodia - an integrated economic analysis. Sida Country Economic Report 2006:2. Stockholm: Swedish International Development Cooperation Agency.

MAFF (2005). Agricultural statistics 2004-2005. Phnom Penh: Ministry of Agriculture, Forestry and Fisheries, Department of Planning, Statistics and International Cooperation.

Mak, S. (2001). Continued innovation in a Cambodian ricebased farming system: farmer testing and recombination of new elements. Agricultural Systems, 69(1-2), 137-149. 
NIS (2003). Cambodian agricultural finance survy 2002: Statistical report. Phnom Penh: Ministry of Planning, National Institute of Statistics.

NIS (2005a). Cambodia socio-economic survey 2004: Summary subject matter report. Phnom Penh: Ministry of Planning, National Institute of Statistics.

NIS (2005b). Statistical yearbook 2005. Phnom Penh: Ministry of Planning, National Institute of Statistics.

NIS (2005c). National Accounts of Cambodia 1993-2004. NIS Bulletin, 9. Phnom Penh: Ministry of Planning, National Institute of Statistics.

Rigg, Jonathan (2006). Land, farming, livelihoods, and poverty: rethinking the links in the rural South. World Development, 34(1), 180-202.

Rostow, W.W. (1956). The take-off into self-sustained growth. Economic Journal, 66(261), 25-48.

Sik Boreak (2000). Land ownership, sales and concentration in Cambodia: A preliminary review of secondary data and primary data from four recent surveys. CDRI Working Paper 16. Phnom Penh: Cambodia Development Resource Institute.

Sjöberg, Örjan \& Sjöholm, Fredrik (2006). The Cambodian economy: ready for take-off? Pacific Review, 19(4), 495-517.

So Savannarith \& Kem Sithen (2005). Moving out of poverty: preliminary findings from two villages - case studies of Ba Baong and Trapeang Prey. In K.A.S. Murshid and Brett M. Ballard (Eds.), Annual development review 2004-05 (pp. 181-199). Phnom Penh: Cambodia Development Resource Institute.

UNDP (2006). Human development report 2006. Beyond scarcity: Power, poverty and the global water crisis. Basingstoke: Palgrave Macmillan. 
Woolard, Ingrid \& Klasen, Stephan (2005). Determinants of income mobility and household poverty dynamics in South Africa. Journal of Development Studies, 41(5), 865-987.

World Bank. World development indicators, online, available from

http://web.worldbank.org/WBSITE/EXTERNAL/DATASTATISTICS/

World Bank (2005). Cambodia rural sector strategy note: Toward a strategy for rural growth and poverty reduction. Phnom Penh: World Bank.

World Bank (2006) Cambodia: Halving Poverty by 2015? Poverty Assessment 2006 (Phnom Penh: World Bank). 


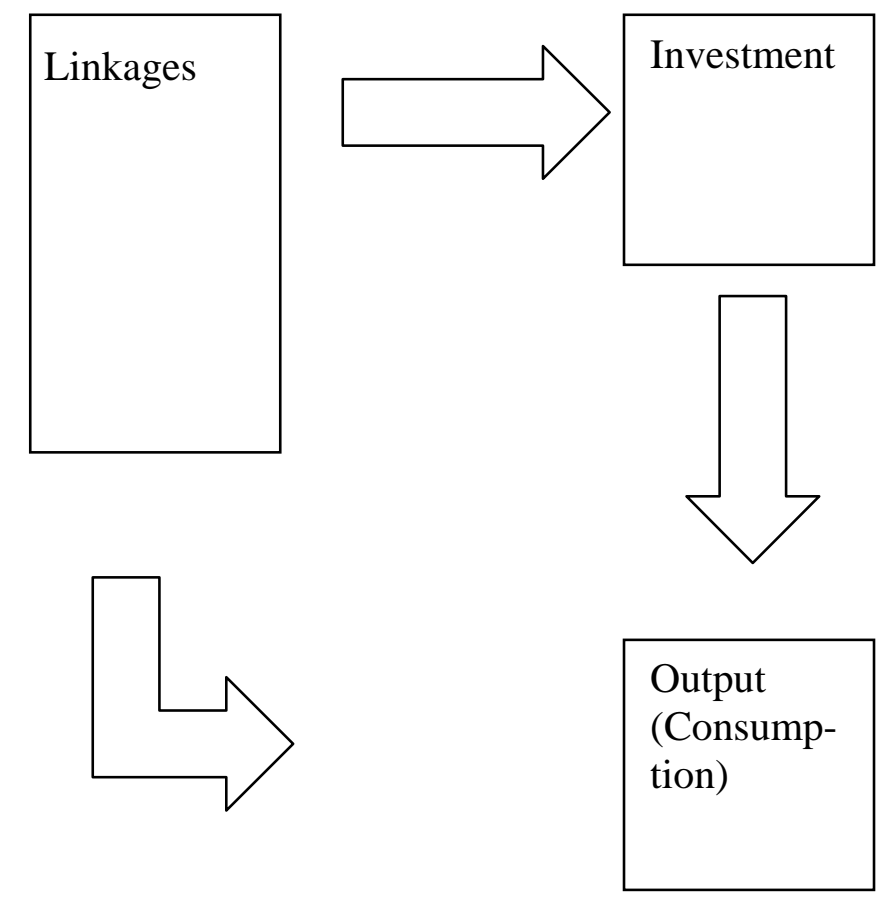

Figure 1. The Relation Between Linkages, Investment, and Output 
Table 1. Poverty in rural and urban Cambodia 1994 and 2004 (\% of population under the poverty line).

1994

\begin{tabular}{lcr}
\hline Rural & 43 & 34 \\
\hline Phnom Penh & 11 & 5 \\
Other urban & 37 & 21 \\
\hline
\end{tabular}

Source: World Bank (2006). 
Table 2 . Rural poverty by provinces

\begin{tabular}{|c|c|c|c|c|}
\hline Region & Province & $\begin{array}{l}\text { Average real } \\
\text { consumption } \\
\text { in riel / day }\end{array}$ & $\begin{array}{c}\text { Average real } \\
\text { consumption } \\
\text { in riel / day - } \\
\text { landless }\end{array}$ & $\begin{array}{r}\text { Poverty } \\
\text { headcount }\end{array}$ \\
\hline Phnom Penh & & 7,046 & 7,097 & 3.2 \\
\hline \multirow[t]{5}{*}{ Plains } & Kandal & 2,893 & 3,155 & 16.0 \\
\hline & Kampong Cham & 2,435 & 2,271 & 30.7 \\
\hline & Prey Veng & 2,308 & 2,263 & 28.1 \\
\hline & Svay Rieng & 2,174 & 1,963 & 30.2 \\
\hline & Takeo & 2,624 & 2,558 & 23.7 \\
\hline \multirow[t]{4}{*}{ Coast } & Kampot & 2,498 & 3,073 & 23.4 \\
\hline & Kep & - & - & - \\
\hline & Koh Kong & 2,533 & 3,829 & 26.6 \\
\hline & Sihanoukville & - & - & - \\
\hline \multirow[t]{6}{*}{ Tonle Sap } & Banteay Meanchey & 2,618 & 3,731 & 31.1 \\
\hline & Battambang & 2,516 & 2,495 & 27.1 \\
\hline & Kampong Chhnang & 2,181 & 2,680 & 32.2 \\
\hline & Kampong Thom & 2,003 & 2,233 & 44.9 \\
\hline & Pursat & 2,215 & 2,073 & 34.1 \\
\hline & Siem Reap & 1,753 & 2,426 & 53.3 \\
\hline \multirow[t]{8}{*}{ Plateau/Mountain } & Kampong Speu & 1,712 & 1,765 & 53.3 \\
\hline & Kratie & 1,951 & 2,144 & 39.5 \\
\hline & Oddar Meanchey & 2,267 & 1,467 & 20.8 \\
\hline & Mondul Kiri & 1,919 & - & 35.0 \\
\hline & Pailin & - & - & - \\
\hline & Preah Vihear & 1,777 & 3,649 & 49.0 \\
\hline & Ratanik Kiri & 2,063 & 2,887 & 45.5 \\
\hline & Stung Treng & 1,047 & 1,664 & 85.0 \\
\hline
\end{tabular}

Source: CSES 2004. 
Table 3. Linkages to other sectors of the economy in rural poor.

\begin{tabular}{|c|c|c|c|c|c|c|c|c|c|c|c|c|}
\hline Region & \multicolumn{2}{|c|}{$\begin{array}{l}\text { Distance to } \\
\text { market, km }\end{array}$} & \multicolumn{2}{|c|}{$\begin{array}{l}\text { Distance to all } \\
\text { weather road, km }\end{array}$} & \multicolumn{2}{|c|}{$\begin{array}{l}\text { Domestic } \\
\text { remittances (share } \\
\text { of households) }\end{array}$} & \multicolumn{2}{|c|}{$\begin{array}{l}\text { Domestic } \\
\text { remittances } \\
\text { (Riel/receiving } \\
\text { household) }\end{array}$} & \multicolumn{2}{|c|}{$\begin{array}{l}\text { Foreign } \\
\text { remittances (share } \\
\text { of households) } \\
\text { Non- }\end{array}$} & \multicolumn{2}{|c|}{$\begin{array}{l}\text { Foreign remittances } \\
\text { (Riel/receiving } \\
\text { household) }\end{array}$} \\
\hline Total & 7.13 & 9.75 & 0.80 & 0.74 & 0.14 & 0.12 & 56,665 & 36,499 & 0.06 & 0.03 & 102,682 & 28,946 \\
\hline $\begin{array}{l}\text { Plains } \\
\text { Tonle }\end{array}$ & 7.3 & 8.4 & 0.75 & 0.70 & 0 . & 01 & 46 , & 37 , & 0.0 & 0.03 & 67 & 12,562 \\
\hline Sap & 7. & 10.8 & & 0 . & & & & & 0 & 0 & & 52,485 \\
\hline Coast & 8. & & 0. & 0 . & & & & & 0. & 0. & & 31,965 \\
\hline Plateau & 11.61 & 13.30 & 0.84 & 0.77 & 0.17 & 0.12 & 64,310 & 46,183 & 0.02 & 0.01 & 12,437 & 11,845 \\
\hline
\end{tabular}

Source: CSES 2004.

Table 4. Agriculture among the rural poor.

\begin{tabular}{|c|c|c|c|c|c|c|c|c|}
\hline Region & \multicolumn{2}{|c|}{$\begin{array}{l}\text { Land area, ha } \\
\text { Non- }\end{array}$} & \multicolumn{2}{|c|}{$\begin{array}{l}\text { Crop } \\
\text { diversification } \\
\text { Non- }\end{array}$} & \multicolumn{2}{|c|}{$\begin{array}{l}\text { Use of fertilizer } \\
\text { (share of } \\
\text { households) } \\
\text { Non- }\end{array}$} & \multicolumn{2}{|c|}{$\begin{array}{l}\text { Access to } \\
\text { irrigation (share of } \\
\text { households) } \\
\text { Non- } \\
\text { Poor Poor }\end{array}$} \\
\hline Total & 2.53 & 2.68 & 0.31 & 0.23 & 0.85 & 0.73 & 0.59 & 0.42 \\
\hline $\begin{array}{l}\text { Plains } \\
\text { Tonle }\end{array}$ & 3.24 & 4.53 & 0.32 & 0.27 & 0.85 & 0.80 & 0.58 & 0.51 \\
\hline Sap & 2.16 & 1.6 & 0.26 & 0.20 & 0.71 & 0.63 & 0.45 & 0.36 \\
\hline Coastal & 1.19 & 0.93 & 0.39 & 0.29 & 0.86 & 0.74 & 0.31 & 0.17 \\
\hline Plateau & 1.23 & 1.39 & 0.29 & 0.18 & 0.60 & 0.55 & 0.34 & 0.32 \\
\hline
\end{tabular}

Source: CSES 2004. 
Table 5. Variables included in the econometric estimations

\begin{tabular}{|c|c|c|c|}
\hline Type of variable & Variable name & Construction & $\begin{array}{l}\text { Expected sign } \\
\text { on consumption }\end{array}$ \\
\hline Dependent & consumption per capita & expenditure in riel & \\
\hline \multirow[t]{5}{*}{ Linkages } & remittances & dummy variable & + \\
\hline & distance to all-weather road & kilometers & - \\
\hline & distance to economic center & kilometers & - \\
\hline & household business & dummy variable & + \\
\hline & employment abroad & dummy variable & + \\
\hline \multirow[t]{7}{*}{ Inputs } & land area & log land area & + \\
\hline & titled land & share of total land & + \\
\hline & irrigated land & share of total land & + \\
\hline & land conflict & dummy variable & - \\
\hline & livestock & conversion units & + \\
\hline & agriculture mechanization & $\begin{array}{l}\text { dummy for tractor } \\
\text { and semi-tractor }\end{array}$ & + \\
\hline & fertilizer & $\begin{array}{l}\text { dummy for chemical } \\
\text { fertilizer }\end{array}$ & + \\
\hline \multirow[t]{5}{*}{$\begin{array}{l}\text { Household control } \\
\text { variables }\end{array}$} & household size & $\begin{array}{l}\text { no. of family } \\
\text { members }\end{array}$ & - \\
\hline & male head of household & dummy variable & $?$ \\
\hline & dependency ratio & $\begin{array}{l}\text { ratio of dependents } \\
(<18 \text { and }>59 \text { years } \\
\text { old }) \text { to adults }\end{array}$ & - \\
\hline & max. formal education & index & + \\
\hline & literate & dummy variable & + \\
\hline \multirow[t]{3}{*}{ Infrastructure } & electricity & dummy variable & + \\
\hline & primary school & dummy variable & + \\
\hline & health service & dummy variable & + \\
\hline
\end{tabular}


Table 6. Staged regression results

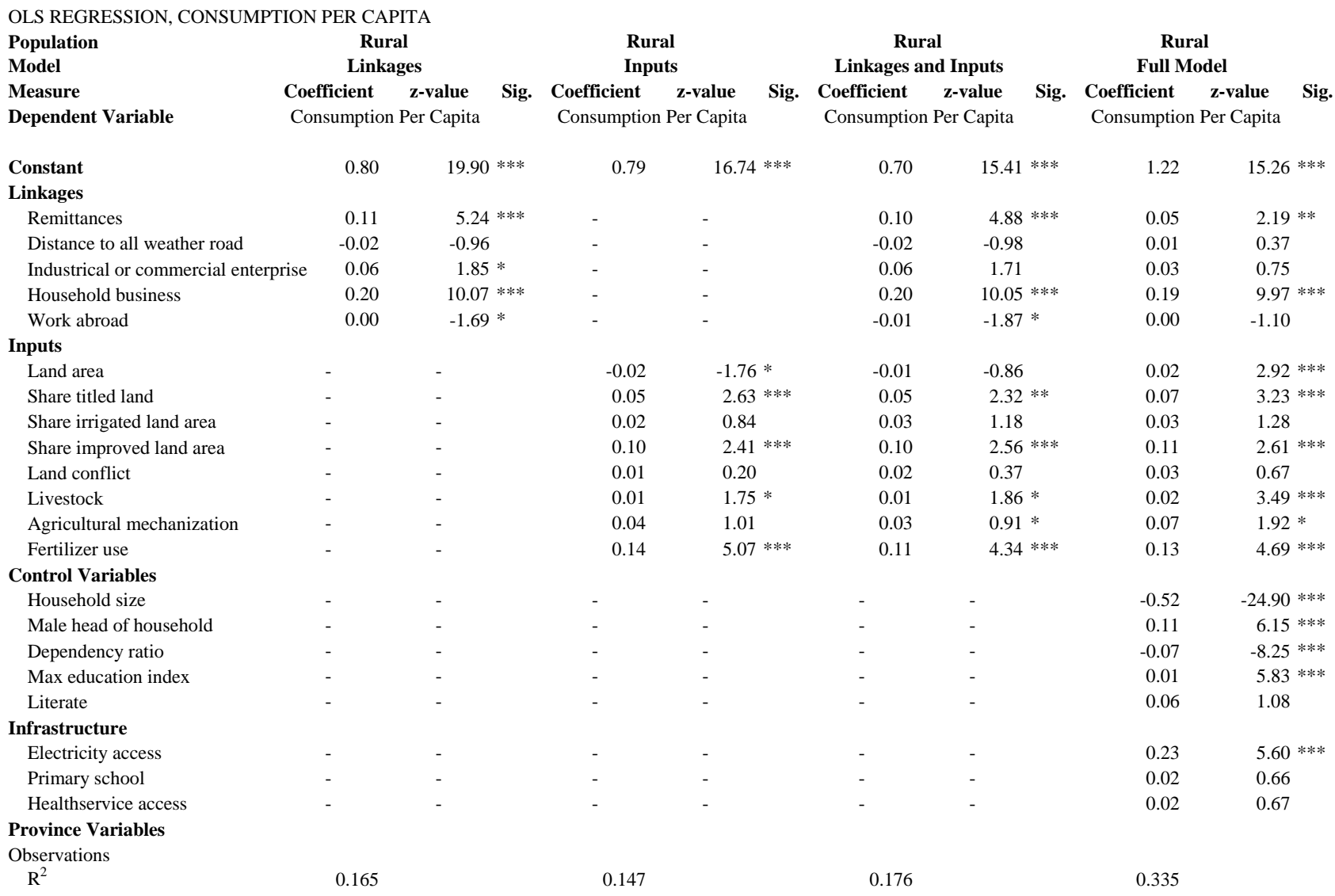

Source: Authors' estimations based on CSES 2004. 
Table 7. Regression results, land owning households

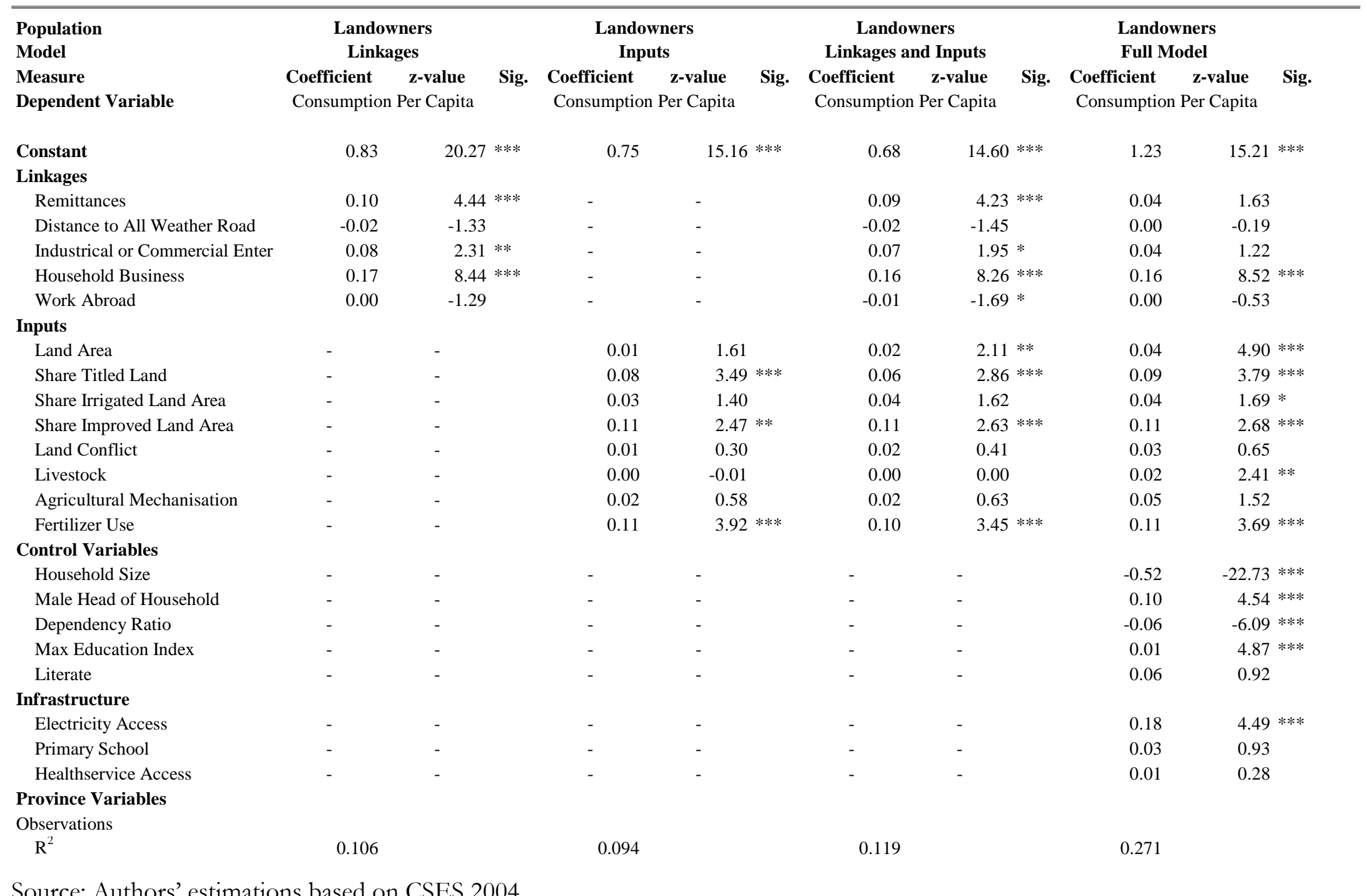


Table 8. Regression results, landless households

\begin{tabular}{|c|c|c|c|c|c|}
\hline \multirow{3}{*}{$\begin{array}{l}\text { Population } \\
\text { Model } \\
\text { Measure } \\
\text { Dependent Variable }\end{array}$} & \multicolumn{2}{|c|}{$\begin{array}{l}\text { Landless } \\
\text { Linkages }\end{array}$} & \multicolumn{3}{|c|}{ Landless } \\
\hline & Coefficient & z-value & Sig. & Coefficient & z-value $\quad \mathrm{Sig}$ \\
\hline & \multicolumn{2}{|c|}{ Consumption Per Capita } & & \multicolumn{2}{|c|}{ Consumption Per Capita } \\
\hline Constant & 0.71 & 11.06 & $* * *$ & 1.22 & $8.46^{* * *}$ \\
\hline \multicolumn{6}{|l|}{ Linkages } \\
\hline Remittances & 0.13 & 3.33 & $* * *$ & 0.12 & $2.43 * *$ \\
\hline Distance to all weather road & 0.01 & 0.52 & & 0.04 & $1.99 * *$ \\
\hline Industrical or commercial enterprise & 0.01 & 0.18 & & 0.00 & 0.03 \\
\hline Household business & 0.29 & 8.29 & $* * *$ & 0.24 & $6.36 * * *$ \\
\hline Work abroad & -0.01 & -1.70 & & -0.01 & $-1.75 *$ \\
\hline \multicolumn{6}{|l|}{ Inputs } \\
\hline Land area & - & - & & - & - \\
\hline Share titled land & - & - & & - & - \\
\hline Share irrigated land area & - & - & & - & - \\
\hline Share improved land area & - & - & & - & - \\
\hline Land conflict & - & - & & - & - \\
\hline Livestock & - & - & & - & - \\
\hline Agricultural mechanization & - & - & & - & - \\
\hline Fertilizer use & - & - & & - & - \\
\hline \multicolumn{6}{|l|}{ Control Variables } \\
\hline Household size & - & - & & -0.50 & $-12.81 * * *$ \\
\hline Male head of household & - & - & & 0.15 & $4.11 * * *$ \\
\hline Dependency ratio & - & - & & -0.11 & $-5.78 * * *$ \\
\hline Max education index & - & - & & 0.02 & $3.62 * * *$ \\
\hline Literate & - & - & & 0.07 & 0.59 \\
\hline \multicolumn{6}{|l|}{ Infrastructure } \\
\hline Electricity access & - & - & & 0.27 & $4.21 * * *$ \\
\hline Primary school & - & - & & -0.02 & -0.32 \\
\hline Healthservice access & - & - & & 0.02 & 0.27 \\
\hline $\mathrm{R}^{2}$ & 0.266 & & & 0.444 & \\
\hline
\end{tabular}


Table 9: Regression results, by region

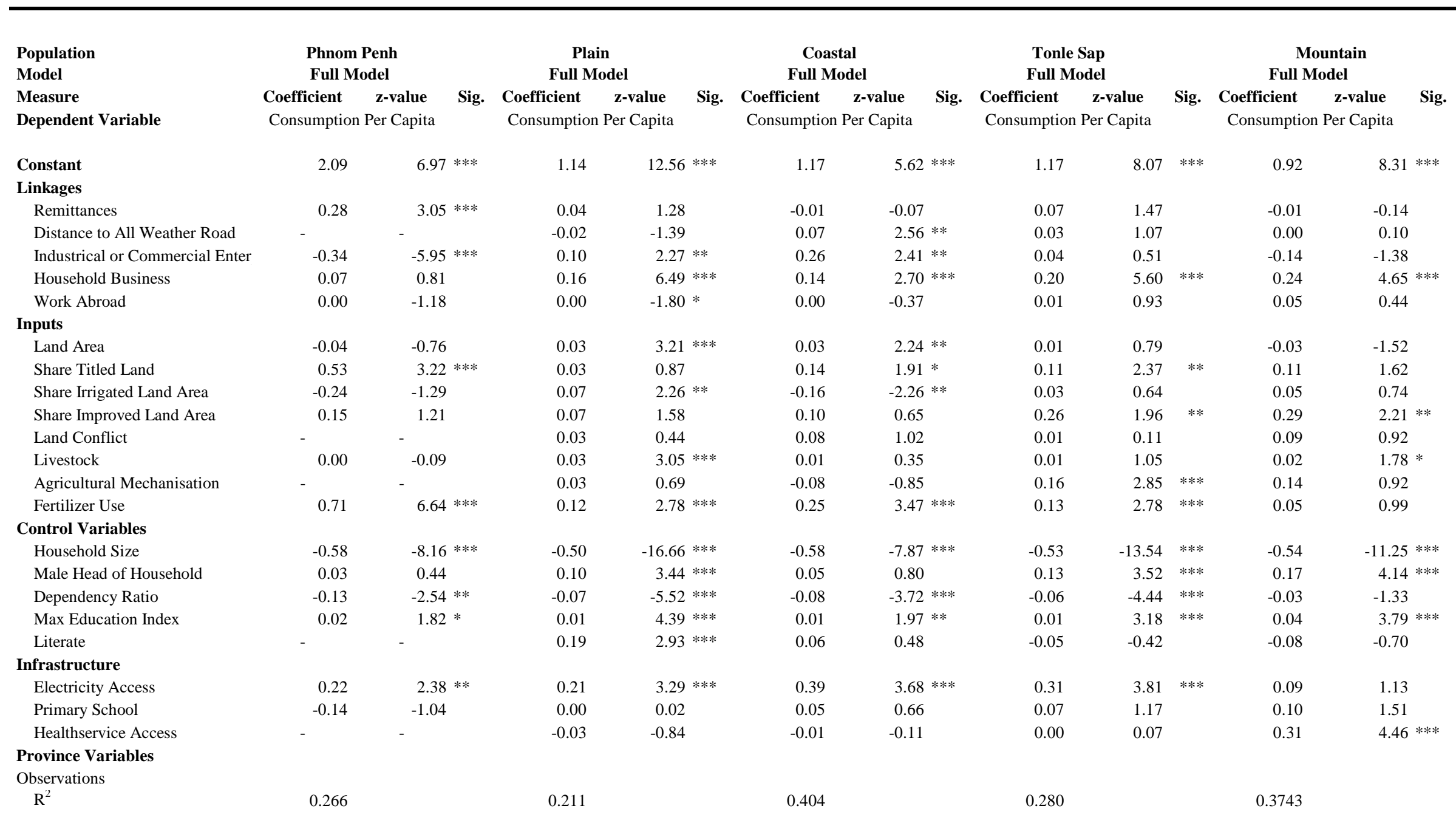

Source: Authors' estimations based on CSES 2004. 